\title{
Comparison of physicochemical parameters in the ground water samples of the fluorotic and nonfluorotic areas of Agastheeswaram Union, South India
}

\author{
A.Anita Joshi Raj ${ }^{1}$, V.Umayoru Bhagan ${ }^{2}$ \\ ${ }^{I}$ (Department of Chemistry, Ponjesly College of Engineering, Anna University, India) \\ ${ }^{2}$ ( N. I. College of Arts and Science, M.S University, India)
}

\begin{abstract}
Fluoride Contamination of ground water is a growing problem in many parts of the world. This paper analyses the most extensive database on fluoride and other physicochemical parameters of 51 ground water samples of ten fluorotic and two nonfluorotic areas of Agastheeswaram Union, South India. The water samples from 10 fluorotic areas were tested and was found to have fluoride level ranging between 1.3 to 2.7 ppm which was greater than the permissible limit. Other parameters such as $\mathrm{pH}$, total handness calcium, magnesium, sodium, potassium, chloride, salinity, alkalinity, electrical conductivity, sulphate, phosphate and aluminium were also measured. These values were compared with the values obtained from nonfluorotic area. Total handness, $\mathrm{pH}$ and alkalinity were found to be higher than the permissible limits in almost all the locations of 10 fluorotic areas at various seasons. Finally it was predicted that as alkalinity increases fluoride level increases in the ground water samples of Agastheeswaram Union.
\end{abstract}

Keywords: Ground water, Fluoride, Fluorotic, Nonfluorotic, Physicochemical

\section{Introduction}

Fluoride contamination of ground water has now become a major geo-environmental issue in many parts of the world due to its toxic effects even if consumed in trace quantities. Fluoride in ground water possess a great problem in most states of India [1]. Seventeen states in India has been identified as endemic for fluorosis and Tamil Nadu is one of them. The amount of fluoride occurring naturally in ground water is governed by climate, composition of host rocks and hydrogeology [2]. The fluoride content is a function of many factors such as availability and solubility of fluoride minerals, velocity of flowing water, temperature, $\mathrm{pH}$, concentration of calcium and bicarbonate ions in water, etc [3].This study was carried out to assess the quality of underground water of ten fluorotic areas (I- Agastheeswaram, II-Anjugramam, III- Marungoor, IV-Mylady, V-South Thamaraikulam, VI-Theroor, VII -Mahadhanapuram, VIII-Theraikalpudur, IX-Kottaram and XNallur) and two nonfluorotic areas (I-Vadiveeswaram and II-Kanyakumari) of Agastheeswaram Union in South India. The fluoride concentrations along with various physicochemical parameters in ground water samples were determined in these regions. Moreover an attempt has been made to statistically correlate the concentrations of fluoride with other parameters and the conditions affecting the ground water quality.

\section{Materials and Methods}

51 underground water samples from ten fluorotic areas and three samples from nonfluorotic areas were collected in precleaned containers of one litre capacity. Temperature was measured immediately after the collection of samples. Water samples were analysed for fluoride within 24 hours of collection. A fluoride ion selective electrode (Orion 9609 BNWP) was used with TISAB-II solution in a 1:1 volume ratio with the samples. For calibration standard solutions containing 0.1, 1.0, 10.0, $100.0 \mathrm{ppm}$ fluoride solutions prepared by serial dilution of a $1000 \mathrm{ppm}$ fluoride stock solution with deionised water were employed. Along with fluoride, other physicochemical parameters were also analysed. The analysis involved the determination of total alkalinity, carbonate, bicarbonate using normal titrations and total hardness using complexometric titration, chloride using argentometric titration, $\mathrm{pH}$ using $\mathrm{pH}$ meter of systronic made, electrical conductivity, aluminum, sulphate and phosphate using UV spectrophotometer, sodium and potassium using flame photometer of systronics made.

\subsection{Temperature}

\section{Results and Discussion}

In the ten fluorotic and two control areas investigated the temperature varied between $28.1^{\circ} \mathrm{C}$ and $36.1^{\circ} \mathrm{C}$. The maximum temperature recorded was in fluorotic area VII in may and the minimum was recorded in fluorotic area I and II in December. According to the survey undertaken in fluorotic areas I to X, the temperature recorded was very high in summer ranging from $30.3^{\circ} \mathrm{C}$ to $36.1^{\circ} \mathrm{C}$. As the temperature was very high in these 
areas the water level in bore wells came down and most of the samples showed higher values of total hardness, calcium, magnesium, electrical conductivity, sodium, chloride and salinity.

\subsection{Fluoride}

Table 4.1 shows the minimum and maximum values of fluoride in fluorotic and nonfluorotic areas. The amount of fluoride present in the ten fluorotic areas were in the range of 1.3 to $2.7 \mathrm{ppm}$. Whereas in the non fluorotic areas the values of fluoride were within the prescribed limit. The concentration of fluoride in water was not uniform in the fluorotic areas. This may be due to the difference in the presence and accessibility of fluoride bearing minerals to the circulating water [4]. The area is devoid of hard rocks and hence the possibility of a source could be the fluoride bearing minerals [5].

\section{$3.3 \mathrm{pH}$}

The minimum and maximum values of hydrogen ion concentrations are given in Table 4.2. Of the ten fluorotic areas the minimum value of 6.8 was found in $\mathrm{V}$ during the month of April and the maximum value of 8.9 was seen in I during the month of October. In general relatively high $\mathrm{pH}$ conditions have a tendency to displace fluoride ions from the mineral surface [6]. These results confirm the findings of the present investigation that as the $\mathrm{pH}$ level in the water becomes higher the fluoride level increases.

\subsection{Electrical Conductivity}

The values of electrical conductivity of all the fluorotic and nonfluorotic areas were given in Table 4.3. The maximum value of $1871 \mathrm{mho} / \mathrm{cm}$ was found in fluorotic area $\mathrm{V}$ during summer season and minimum of $913 \mathrm{mho} / \mathrm{cm}$ was seen in fluorotic area VI during rainy season. The low values of electrical conductivity indicate the lesser dissolution of carbonate minerals and other ionic species in water [7]. This causes the lowering of the conditions for the availability of fluoride [8].

\subsection{Calcium}

Table 4.4 shows the amount of calcium present in the ground water samples of ten fluorotic and two nonfluorotic areas. Of the ten fluorotic areas analysed fluorotic area VII showed the maximum of $250 \mathrm{ppm}$ of calcium hardness during the month of April and fluorotic area IX showed the minimum of $15 \mathrm{ppm}$ during the month of october. It is an established fact that the water high in calcium are low in fluoride content [9]. Accordingly in the present investigation samples with low calcium had high fluoride levels.

\subsection{Magnesium}

The amount of magnesium present in the samples from the ten fluorotic areas are shown in Table 4.4. Of the ten fluorotic areas the fluorotic area VII showed the maximum of $118 \mathrm{ppm}$ magnesium hardness and the fluorotic area III recorded the minimum of $7 \mathrm{ppm}$. Among the two nonfluorotic areas the maximum and minimum values were recorded in nonfluorotic area I and also those values were within the prescribed limit. In the summer season the values of magnesium hardness are higher than in the rainy season. This is due to the dilution of water. Hence magnesium is also one of the factors influencing the fluoride toxicity.

\subsection{Total hardness}

The results obtained for total hardness in the ten fluorotic and two nonfluorotic areas are given in Table 4.5. Among the ten fluorotic areas analysed, the fluorotic area VII was having maximum value of $341 \mathrm{ppm}$ and the minimum value was recorded in fluorotic areas II and III. Teotia et.al [10] have observed that increasing content of fluoride in water means a decrease in hardness. This applies to the majority of the samples. However in a few samples, as fluoride content in water increased, hardness also increased.

\subsection{Carbonate and Bicarbonate}

Table 4.6 shows the minimum and maximum values of carbonate and bicarbonate of ten fluorotic and two nonfluorotic areas. In the ten fluorotic areas the minimum value of carbonate was recorded in fluorotic area $\mathrm{V}$ and maximum of 73ppm was recorded in fluorotic area $\mathrm{X}$. The minimum value of bicarbonate was found in fluorotic area $\mathrm{X}$ and maximum value of $643 \mathrm{ppm}$ at $\mathrm{V}$. It was noticed that almost all the samples had higher bicarbonate values than carbonate. So ground water of the study area are of bicarbonate type [11]. A positive relationship between fluoride and bicarbonate ion was observed as the concentration of bicarbonate was maximum [12].

\subsection{Total alkalinity}

The values of total alkalinity in the ten fluorotic and two nonfluorotic areas were given in the table 4.7. Higher values of alkalinity more than 600ppm was observed in fluorotic areas I,II,III, IV, V, VI, VII and VIII 
during the months of October, November and December when compared to summer season. During this period more fluoride concentration was also seen in the same areas. Where as in the nonfluorotic areas the values of total alkalinity and fluoride were within the prescribed limit. Hence no one was affected by fluorosis here. Saxena et.al [13] have observed that $\mathrm{pH}$ and fluoride has positive correlation, indicating that higher alkalinity of water promotes leaching of fluoride and thus affects the concentration of fluoride in the ground water.

\subsection{Chloride and salinity}

Table 4.8 shows the amount of chloride and salinity in the ground water samples of ten fluorotic and two nonfluorotic areas. Of the fluorotic areas, $\mathrm{V}$ showed the maximum values of chloride and salinity and fluorotic area I showed the minimum value of chloride and salinity. Higher values of chloride were seen during the month of April chloride did not show any correlation with fluoride content, ruling out evaporation as a reason for high fluoride content [14].

\subsection{Sodium and Potassium}

The levels of sodium and potassium in ten fluorotic and two nonfluorotic areas are given in table 4.9. Among the fluorotic areas, area II shows the maximum of $316 \mathrm{ppm}$ and minimum of $14 \mathrm{ppm}$ of sodium levels. Maximum value of potassium is seen in fluorotic area IV and minimum of $9.4 \mathrm{ppm}$ in VI. In the nonfluorotic areas both the values were within the prescribed limit. In the fluorotic areas majority of the samples were found to have higher sodium content than potassium. Therefore sodium and potassium are also the factors enhancing fluoride toxicity.

\subsection{Sulphate}

The amount of sulphate present in the ground water samples of ten fluorotic and two nonfluorotic are shown in Table 4.10. Among the fluorotic areas the maximum value was seen in VIII (65 ppm) and minimum of $0.42 \mathrm{ppm}$ in II. Both these values were within the prescribed limit. The concentration of sulphate in the nonfluoritc areas were also found to be within the prescribed limit.

\subsection{Phosphate}

The phosphate levels in the ground water sources are shows in Table 4.11. Maximum value of $0.8 \mathrm{ppm}$ was found in fluorotic area IV and minimum value of $0.01 \mathrm{ppm}$ was found in fluorotic areas II,III,IV,IX and X. The Phosphate values in all the fluorotic and nonfluorotic areas were within the prescribed limit.

\subsection{Aluminium}

The aluminium levels in the ground water sources are shown in Table 4.12. Maximum value of $0.06 \mathrm{ppm}$ was measured in fluorotic area I and III and minimum of $0.01 \mathrm{ppm}$ was found in I, II, III, IV, V, VI and VIII. The presence of residual aluminium in drinking water has become a major concern for public health. The WHO limit [15] for aluminium in drinking water is between $0.03 \mathrm{ppm}$ to $0.2 \mathrm{ppm}$. The values of aluminum in many of the fluorotic areas were found to be very low. Whereas the values in nonfluorotic areas were within the prescribed limit.

\section{Tables}

Table : 4.1 Levels of fluoride in fluorotic and nonfluorotic areas

\begin{tabular}{|c|c|c|}
\hline \multirow{2}{*}{ Fluorotic Areas } & Minimum & Maximum \\
\cline { 2 - 3 } & $(\mathrm{ppm})$ & $(\mathrm{ppm})$ \\
\hline I & 1.5 & 2.7 \\
\hline II & 2.0 & 2.6 \\
\hline III & 1.6 & 2.1 \\
\hline IV & 1.6 & 2.2 \\
\hline V & 1.5 & 2.0 \\
\hline VI & 1.6 & 2.1 \\
\hline VII & 1.9 & 2.1 \\
\hline VIII & 1.5 & 1.7 \\
\hline IX & 1.4 & 2.0 \\
\hline X & 1.3 & 1.9 \\
\hline $\begin{array}{c}\text { Nonfluorotic } \\
\text { areas }\end{array}$ & & \\
\hline
\end{tabular}




\begin{tabular}{|c|l|l|}
\hline I & 0.7 & 0.8 \\
\hline II & 0.7 & 0.8 \\
\hline
\end{tabular}

Table: 4.2 Levels of $\mathrm{pH}$ in fluorotic and nonfluorotic areas

\begin{tabular}{|c|c|c|}
\hline \multirow{2}{*}{ Fluorotic areas } & Minimum & Maximum \\
\hline I & 7.2 & 8.9 \\
\hline II & 7.3 & 8.7 \\
\hline III & 7.3 & 8.6 \\
\hline IV & 6.9 & 8.6 \\
\hline V & 6.8 & 8.7 \\
\hline VI & 7.3 & 8.5 \\
\hline VII & 7.5 & 8.5 \\
\hline VIII & 7.4 & 8.5 \\
\hline IX & 7.5 & 8.5 \\
\hline X & 7.2 & 8.4 \\
\hline Nonfluorotic & & \\
areas & & 7.8 \\
\hline I & 7.2 & 7.8 \\
\hline II & 7.6 & \\
\hline
\end{tabular}

Table : 4.3 Levels of electrical conductivity in fluorotic and nonfluorotic areas

\begin{tabular}{|c|c|c|}
\hline \multirow{2}{*}{ Fluorotic areas } & Minimum & Maximum \\
\cline { 2 - 3 } & $(\mathrm{mho} / \mathrm{cm})$ & $(\mathrm{mho} / \mathrm{cm})$ \\
\hline I & 1540 & 1720 \\
\hline II & 938 & 1340 \\
\hline III & 1299 & 1624 \\
\hline IV & 1430 & 1817 \\
\hline V & 1620 & 1871 \\
\hline VI & 913 & 1223 \\
\hline VII & 1001 & 1521 \\
\hline VIII & 1002 & 1691 \\
\hline IX & 1360 & 1559 \\
\hline X & 1108 & 1326 \\
\hline $\begin{array}{c}\text { Nonfluorotic } \\
\text { areas }\end{array}$ & & \\
\hline I & 902 & 1020 \\
\hline II & 861 & 1010 \\
\hline
\end{tabular}

Tables : 4.4 Levels of calcium and magnesium in fluorotic and nonfluorotic areas

\begin{tabular}{|c|c|c|c|c|}
\hline \multirow{2}{*}{ Fluorotic areas } & \multicolumn{2}{|c|}{ Calcium } & \multicolumn{2}{c|}{ Magnesium } \\
\cline { 2 - 5 } & Minimum & Maximum & Minimum & Maximum \\
\cline { 2 - 5 } & $(\mathrm{ppm})$ & $(\mathrm{ppm})$ & $(\mathrm{ppm})$ & $(\mathrm{ppm})$ \\
\hline I & 61 & 135 & 11 & 81 \\
\hline II & 43 & 185 & 22 & 55 \\
\hline III & 50 & 130 & 7 & 81 \\
\hline IV & 61 & 161 & 17 & 89 \\
\hline V & 53 & 177 & 21 & 97 \\
\hline
\end{tabular}




\begin{tabular}{|c|c|c|c|c|}
\hline VI & 43 & 138 & 22 & 63 \\
\hline VII & 98 & 250 & 15 & 118 \\
\hline VIII & 90 & 146 & 16 & 37 \\
\hline IX & 15 & 230 & 20 & 95 \\
\hline X & 62 & 120 & 30 & 56 \\
\hline $\begin{array}{c}\text { Nonfluorotic } \\
\text { areas }\end{array}$ & & & & \\
\hline I & 81 & 233 & 15 & 50 \\
\hline II & 88 & 253 & 22 & 28 \\
\hline
\end{tabular}

Table : 4.5 Levels of total hardness in fluorotic and nonfluorotic

\begin{tabular}{|c|c|c|}
\hline \multirow{2}{*}{ Fluorotic areas } & Minimum & Maximum \\
\cline { 2 - 3 } & $(\mathrm{ppm})$ & $(\mathrm{ppm})$ \\
\hline I & 101 & 174 \\
\hline II & 67 & 205 \\
\hline III & 62 & 183 \\
\hline IV & 90 & 201 \\
\hline V & 100 & 239 \\
\hline VI & 97 & 164 \\
\hline VII & 141 & 341 \\
\hline VIII & 110 & 163 \\
\hline IX & 101 & 270 \\
\hline X & 110 & 159 \\
\hline Nonfluorotic & & \\
\hline areas & & 279 \\
\hline I & 104 & 281 \\
\hline II & 100 & \\
\hline
\end{tabular}

Table : 4.6 Levels of carbonate and bicarbonate influorotic and nonfluorotic areas

\begin{tabular}{|c|c|c|c|c|}
\hline \multirow{2}{*}{ Fluorotic areas } & \multicolumn{2}{|c|}{ Carbonate } & \multicolumn{2}{c|}{ Bicarbonate } \\
\cline { 2 - 5 } & Minimum & Maximum & Minimum & Maximum \\
\cline { 2 - 5 } & $(\mathrm{ppm})$ & $(\mathrm{ppm})$ & $(\mathrm{ppm})$ & $(\mathrm{ppm})$ \\
\hline I & 20 & 197 & 193 & 379 \\
\hline II & 17 & 145 & 274 & 396 \\
\hline III & 18 & 192 & 59 & 442 \\
\hline IV & 35 & 184 & 223 & 445 \\
\hline V & 10 & 172 & 291 & 643 \\
\hline VI & 28 & 191 & 167 & 393 \\
\hline VII & 29 & 198 & 139 & 581 \\
\hline VIII & 14 & 196 & 220 & 464 \\
\hline IX & 25 & 193 & 102 & 465 \\
\hline X & 73 & 165 & 72 & 467 \\
\hline Nonfluorotic & & & & \\
\hline areas & & 89 & 207 & 264 \\
\hline I & 31 & 138 & 208 & 270 \\
\hline II & 29 & & & \\
\hline
\end{tabular}


Table : 4.7 Levels of total alkalinity in fluorotic and nonfluorotic areas

\begin{tabular}{|c|c|c|}
\hline \multirow{2}{*}{ Fluorotic areas } & Minimum & Maximum \\
\cline { 2 - 3 } & $(\mathrm{ppm})$ & $(\mathrm{ppm})$ \\
\hline I & 236 & 495 \\
\hline II & 310 & 489 \\
\hline III & 220 & 595 \\
\hline IV & 326 & 605 \\
\hline V & 344 & 695 \\
\hline VI & 231 & 584 \\
\hline VII & 174 & 628 \\
\hline VIII & 234 & 652 \\
\hline IX & 154 & 565 \\
\hline X & 145 & 632 \\
\hline $\begin{array}{c}\text { Nonfluorotic } \\
\text { areas }\end{array}$ & & \\
\hline I & 266 & 299 \\
\hline II & 292 & 346 \\
\hline
\end{tabular}

Table: 4.8 Levels of chloride and salinity in fluorotic and nonfluorotic areas

\begin{tabular}{|c|c|c|c|c|}
\hline \multirow{2}{*}{ Fluorotic areas } & \multicolumn{2}{|c|}{ Chloride } & \multicolumn{2}{c|}{ Salinity } \\
\cline { 2 - 5 } & Minimum & Maximum & Minimum & Maximum \\
\cline { 2 - 5 } & $(\mathrm{ppm})$ & $(\mathrm{ppm})$ & $(\mathrm{ppm})$ & $(\mathrm{ppm})$ \\
\hline I & 8 & 92 & 14 & 166 \\
\hline II & 36 & 123 & 65 & 223 \\
\hline III & 201 & 206 & 362 & 372 \\
\hline IV & 103 & 120 & 186 & 216 \\
\hline V & 129 & 229 & 236 & 413 \\
\hline VI & 132 & 184 & 238 & 332 \\
\hline VII & 127 & 184 & 230 & 332 \\
\hline VIII & 132 & 158 & 238 & 283 \\
\hline IX & 127 & 208 & 230 & 375 \\
\hline X & 193 & 208 & 354 & 375 \\
\hline Nonfluorotic & & & & \\
\hline areas & & 69 & 124 & 125 \\
\hline I & 68 & 76 & 58 & 137 \\
\hline II & 32 & & & \\
\hline
\end{tabular}

Table: 4.9 Levels of sodium and potassium in fluorotic and nonfluorotic areas

\begin{tabular}{|c|c|c|c|c|}
\hline \multirow{2}{*}{ Fluorotic areas } & \multicolumn{2}{|c|}{ Sodium } & \multicolumn{2}{c|}{ Potassium } \\
\cline { 2 - 5 } & Minimum & Maximum & Minimum & Maximum \\
\cline { 2 - 5 } & $(\mathrm{ppm})$ & $(\mathrm{ppm})$ & $(\mathrm{ppm})$ & $(\mathrm{ppm})$ \\
\hline I & 25 & 92 & 3 & 38 \\
\hline II & 83 & 316 & 1.1 & 14.8 \\
\hline III & 52 & 241 & 13 & 61 \\
\hline IV & 201 & 285 & 54 & 81 \\
\hline V & 98 & 206 & 6.1 & 14.8 \\
\hline VI & 73 & 133 & 3.9 & 9.4 \\
\hline VII & 14 & 90 & 7 & 21 \\
\hline
\end{tabular}




\begin{tabular}{|c|c|c|c|c|}
\hline VIII & 75 & 78 & 10 & 16 \\
\hline IX & 130 & 238 & 5 & 11.4 \\
\hline X & 173 & 225 & 55 & 66 \\
\hline $\begin{array}{c}\text { Nonfluorotic } \\
\text { areas }\end{array}$ & & & & \\
\hline I & 72 & 86 & 5.1 & 5.6 \\
\hline II & 62 & 152 & 3.3 & 7.5 \\
\hline
\end{tabular}

Table: 4.10 Levels of sulphate in fluorotic and nonfluorotic areas

\begin{tabular}{|c|c|c|}
\hline \multirow{2}{*}{ Fluorotic areas } & Minimum & Maximum \\
\cline { 2 - 3 } & $(\mathrm{ppm})$ & $(\mathrm{ppm})$ \\
\hline I & 0.46 & 8.01 \\
\hline II & 0.42 & 4.67 \\
\hline III & 1.1 & 4.5 \\
\hline IV & 6 & 27 \\
\hline V & 3.16 & 6.25 \\
\hline VI & 20 & 37 \\
\hline VII & 20 & 47 \\
\hline VIII & 14 & 65 \\
\hline IX & 1.12 & 4.81 \\
\hline X & 1.06 & 1.35 \\
\hline Nonfluorotic & & \\
\hline areas & & 1.43 \\
\hline I & 0.41 & 1.43 \\
\hline II & 0.51 & \\
\hline \multicolumn{2}{|c|}{} \\
\hline
\end{tabular}

Table: 4.11 Levels of phosphate in fluorotic and nonfluorotic areas

\begin{tabular}{|c|c|c|}
\hline \multirow{2}{*}{ Fluorotic areas } & Minimum & Maximum \\
\cline { 2 - 3 } & $(\mathrm{ppm})$ & $(\mathrm{ppm})$ \\
\hline I & 0.02 & 0.54 \\
\hline II & 0.01 & 0.05 \\
\hline III & 0.01 & 0.07 \\
\hline IV & 0.02 & 0.8 \\
\hline V & 0.01 & 0.07 \\
\hline VI & 0.02 & 0.23 \\
\hline VII & 0.02 & 0.04 \\
\hline VIII & 0.03 & 0.05 \\
\hline IX & 0.01 & 0.06 \\
\hline X & 0.01 & 0.04 \\
\hline $\begin{array}{c}\text { Nonfluorotic } \\
\text { areas }\end{array}$ & & \\
\hline I & 0.02 & 0.04 \\
\hline II & 0.02 & 0.05 \\
\hline
\end{tabular}


Table : 4.12 Levels of aluminum in fluorotic and nonfluorotic areas

\begin{tabular}{|c|c|c|}
\hline \multirow{2}{*}{ Fluorotic areas } & Minimum & Maximum \\
\cline { 2 - 3 } & $(\mathrm{ppm})$ & $(\mathrm{ppm})$ \\
\hline I & 0.01 & 0.06 \\
\hline $\mathrm{II}$ & 0.01 & 0.05 \\
\hline III & 0.01 & 0.06 \\
\hline IV & 0.01 & 0.05 \\
\hline V & 0.01 & 0.04 \\
\hline VI & 0.01 & 0.03 \\
\hline VII & 0.02 & 0.03 \\
\hline VIII & 0.01 & 0.03 \\
\hline IX & 0.03 & 0.04 \\
\hline X & 0.03 & 0.05 \\
\hline $\begin{array}{c}\text { Nonfluorotic } \\
\text { areas }\end{array}$ & & \\
\hline I & 0.03 & 0.04 \\
\hline II & 0.03 & 0.05 \\
\hline \multicolumn{2}{|c|}{} \\
\hline
\end{tabular}

\section{Conclusion}

The ground water sources in the Agastheeswaram Union of Kanyakumari District, South India have been evaluated for its chemical composition and suitability for domestic uses with special concern of fluoride. Most of the samples do not meet the water quality standards for fluoride concentration and other quality parameters such as alkalinity, $\mathrm{pH}$ and hardness. Hence, it is not suitable for consumption without any prior treatment. Villagers should be educated about the hazards of consumption of high fluoride bearing water and use of simple methods of defluoridation using locally available low cost adsorbents. More emphasis must be given to calcium and phosphorus rich food as its intake helps in reduction in the absorption of fluoride in the intestine.

\section{References}

[1] D. Muralidharan, A.P. Nair and U. Sathyanarayana, Current Science, 83, 2002, 699-702.

[2] S. Gupta, S. Banerjee, R. Saha, J.K. Datta and N. Mondal, Fluoride geochemistry of ground water in Birbhum, West Bengal, India, Fluoride, 39, 2006, 318-320.

[3] Garg, Kavitha, Renuka and Anju Malik, Ground water quality in some villages of Haryana, India : Focus on fluoride and fluorosis, Jour. Hazard, Mater, 106 B, 2004, 85-97.

[4] Meenakshi, R.C. Maheshwari, J. Hazard Material, 37, 2006, 456

[5] K. Ramesh, Vennila Soorya, Fluoride Contamination in drinking water in Palacode region, Tamil Nadu, International Journal of Research in Chemistry and Environment, 2(1), 2012, 116-123.

[6] Sanjay Kumar, J.W. Bhatta Cherjee and R.K. Sharma, Relationship between fluoride, total hardness and total alkalinity in the ground water of Barmer district, Poll.Res, 11, 1992, 111-116.

[7] B. Tutmeza, Z. Hatipogub and U. Kaymak, Modelling electrical conductivity of ground water using an adaptive neurofuzzy interference system,Comput. Geoscience, 32, 2009, 421-433.

[8] G. Jacks, P. Bhattacharya, V. Chaudhary and K.P. Singh, Controls on the genesis of some high fluoride waters in India, Appl. Geochem, 20, 2005, 221-228.

[9] J.D. Hem, U.S. Geol. Survey, Water Supply Paper, 2254, 1985, 264.

[10] S.P. S. Teotia, M. Teotia and R. K. Singh, Hydrogeochemical aspects of endemic skeletal fluorosis in India - an epidemiological study, Meerut, India, Fluoride, 14, (2), 1981, 69.

[11] Hydrogeological study of the occurrence of fluoride in ground water in parts of pandharkawada tahsil, Yavatmal district, Maharashtra state. Technical report, Central Ground Water Board, Ministry of Water Resources, Govt. of India, $2002,18$.

[12] N. Subba Rao and A.T. Rao, Fluoride in ground water in a developing area of Guntur district, Andhra Pradesh, India, Journal of Appl. Geochem, 5, 2003, 94-100.

[13] V.K. Saxena and S. Ahmed, Dissolution of fluoride in ground water, A water - rock interaction study, Environ. Geol, 40, 2001,1084-1087.

[14] P.L. Smedley, D.G. Kinningburgh, Appl. Geochem, 17, 2002,517-568.

[15] WHO, Guidelines for drinking water quality. World Health Organisation, Geneva, 2, 1984, 249. 